\title{
Innovation Policy of a Regional Paper in Semarang, Indonesia
}

\author{
Sunarto*, Adi Nugroho \\ Lecturers of Communication Department \\ Diponegoro University \\ Semarang, Indonesia \\ (sunartoo@yahoo.com)
}

\author{
Heni Indrayana, Agus Toto \\ Students of Post Graduate Program in Communication \\ Department, \\ Diponegoro University \\ Semarang, Indonesia
}

\begin{abstract}
The future of regional newspapers in Indonesia are not good enough economically. Competition between regional papers themselves and the encouraging of communication technology are among problems that be faced by the papers. How do the papers solve the problem to support their economical life in the future? Based on a case of a biggest local paper that be published in Semarang, Central Java, Indonesia, namely Harian Suara Merdeka be found that publishing on line version, serving its community and changing editorial policy may be a way out to be solved their economic problems.
\end{abstract}

Keywords—Local Paper; Community Service

\section{INTRODUCTION}

The future of newspapers globally and regionally is not good enough. There is several predictiont that said about that. The progress of digital technology, the slow of economical development, the shift of reading habit from print media to online media, and the new reader from youth generation not yet developed were factor that made the papers faced the economical problems (Haryanto, 2016: 7; Bagdikian, 2004: 114-117). How the papers solve the problem was the main issue that faced by all the papers recently. The regional paper also faced the same problem. How the regional papers solve the problem become the main objective in this article.

According Albarran (2006: 8), leadership is one approach that can be used in media management study in this century. The most successful organizations have strong and effective leaders. The leaders who have vision, passion, and integrity in them selves will be successful leader.

To be success, a leader has to has positive attitudes, such as daring to take risk and being creative to solve the problems and being innovative in social condition (Northouse, 2013: 21).

According Sylvie, Wicks, Hollifield, Lacy, dan Sohn (2008: 30-33), facing the development of communication technology recently is needed changing media management orientation. What kinds of management orientation which may be done by a regional paper that will be relevant with its context?

\section{METHOD}

This research was used descriptive qualitative approach in interpretive paradigm. Phenomenology strategy was used to answer the questions. Data was collected in depth interview with a chief executive officer (CEO) and a head of editor of a regional newspaper in Semarang, Central Java, Indonesia, namely Harian Suara Merdeka (Independent Voice Daily).

\section{Result of RESEARCH}

Suara Merdeka was created firstly on February 11, 1950. It was leaded by the founder, Hetami. Then it was conducted by Budi Santoso. Now it is leaded by Kukrit Suryo Wicaksono. It has several bussiness units in media industries such as Tabloid Otospeed Tabloid, Tabloid Cempaka Tabloid, Harian Sore Wawasan (print media), Suara Sakti FM, and Track FM (electronic media). In March 1 in 1996, it created Suara Merdeka Cybernews (www.suaramerdeka.com) as the first site news in Indonesia (Machmud and Triwikromo, 2010: 18).

In 2015, Suara Merdeka was rewarded as the best regional paper in Java and Bali island by Serikat Penerbit Suratkabar Indonesia (Indonesian Union Press Publishers). Solving the economical problems that faced by print media globally and regionally and the progress of communication technology recently, it had several strategies to survive and grow up to adapt with the recent condition. Firstly, developing the paper becomes a referent paper to Central Java community. Using the newest communication technologies, it was created as a marketing services and a marketing company. Secondly, changing news policy from publishing talk news (hard news) becomes story news (soft news).

\section{DISCUSSION}

\section{A. Product to Value: Marketing 3.0 Strategy}

Related with the first finding, the paper changed its service orientation from product to value. What is meant? According to its CEO, in the past, about 20-25 years ago, in the first and second generation owner, the paper used the product as main orientation. This strategy was done since the competition of the papers in that time did not like up to know. There was no digital media. The number of print and electronic media in Indonesia was still limited. Public had no more choice to consume media. So, whatever the media content gave to them, it would be consumed. The recent condition is very different. Recently, there is very large number of media: print, electronic, and digital. The media market becomes very competitive.

Continuing the exist, the paper must change its orientation. The paper will not win in the competition with digital media if only serve the product not the service. By the service, it means 
the paper will serve its community with all information that be needed personally and communally. Personally, it serves the information about hobbies, culinary, recreation, meeting, business, and so on. For regional government, the paper will serve as public relations tool. The paper attends in society as social problem solver together with regional government not as a problem maker. The paper gives solutions to regional government to solve social problem in its regions. Besides, the employees must serve as a chief or member in communality forums such as Ketua RT, Ketua RW (chief of village communality), Chief of Drone Photography, Chief of Regional Business Organization, etc. All services will support the business media to increase economical, political, and social networking. Shortly speaking, it serves public in Central Java with values as a partner in solving problem personally and communally.

According to Kotler, Kartajaya and Setiawan (2010: 3-5), what is done by the paper is marketing 3.0. The paper does not just sell the product, but also the values to the consumers. What values? Giving regional referent and getting solution to the society problems!

Marketing 3.0 believes that consumers are complete human that all their needs and hopes must not be obeyed. The paper not just serve the consumers with all information that be needed but also the direct services in society to solve problems. The new wave technology is the main factor that pulls the regional paper using marketing 3.0 strategies.

According to the CEO, his paper develops into pioneer news online in Indonesia. It was published firstly in 1996. Recently, he used the new technology to support its paper in many business applications such as dalkot as source of everything want to know about Semarang. In the applications, public may get information about Semarang: events, point of interests, local communities, lifestyles, movies, restaurants, etc. After Semarang, it will reach other big cities like Solo, Yogyakarta, etc. Besides, he also develops e-commerce such as getasean.com that encouraged regional business units at Central Java going international. By cooperation with regional government and regional business organization, the paper serves the regional business units to promote their product in ASEAN countries. In the first time, the paper will not charge financially to the units. In the future, the units will be charge when using the application to promote their products. It is another innovative policy that be created by the paper to support its economical interests.

Marketing 3.0 business strategy was developed by three forces namely the age of participatory, the age of paradox globalization, and the age of creative society (Kotler, Kartajaya and Setiawan (2010: 5-23).

The first one is related with the progress of information technology which known as new wave technology. It may create connectivity and interactivity among individuals and groups. It includes cheap computer and hand phone, cheap internet, and open source. It create expressive social media (blog, Twitter, YouTube, Facebook, Instagram, etc) and collaborative social media (Wikipedia).
The second factor is related with globalization which is moved by technology. Globalization creates a balancing position. In pursuing the position, often it creates paradox: capitalism need no democracy, economy integration do not create economy equality and homogeneousness. It creates differentiate cultures.

Creative society is the third factor that creates marketing 3.0. It is related with people who may optimize their right brain potentiality such as science, art, and expert services. It is the highest rank in social development of human kind. Technology becomes a stimulant to the development.

\section{B. Talk News to Story News}

The second finding related with the content of the paper. Usually the paper serves the public with information based on talk news. It means, the paper gets information from its sources and publishes it in hard news genre. Recently the policy is changed by publishing story news which gives many detail of information in soft news genre. It is an idealistic format to challenge the fast information that be served by news online. The problem is that kind of news relevant with the consumers' needs? According the chief of editor, he wants to educate their readers become quality readers who do not satisfy just with fast information without in depth meaning.

Is it true that story news has higher quality than talk news? What is news? According to Newsom and Wollert (1985: 1112), news is what people want and need to know. By reporting news, the mass media provide people the information they need to function in a democratic society. Events and situations regarded as newsworthy have certain characteristics in common such as unusual, new, has impact, interesting, timely, nearby, information, conflict, about people, and surprising. The characteristics are still relevant recently. It may be checked on Sumpter (2009: 1002) and O'Neill and Harcup (2009: 161-172). It is all news values. Something (events, objects) or someone (people) may become news if it has news values.

All news has in itself three basic things: honesty, accuracy, and fairness. Good journalists must keep the basic elements in doing their profession. Without that, they may lose their trust from its readers. If the readers do have no trust, the paper must be collapsed and died. So, all the elements have to include in all the genre or format of news.

There are two kinds of news format: hard news and soft news (Bell, 2009: 687). Hard news format is the embodiment of the "watchdog" or observational role of journalism. It indicates events that are current and time-sensitive. Its major purpose of hard news is to inform.

How is about soft news? According to Bell, soft news is everything else. It can be applied to human interest stories, arts and entertainment, sports, celebrity gossip, society pages, and similar topics. It is less time-sensitive and covering topics that are not viewed as seriously or having as great a social impact as hard news coverage. It may be called as feature material. Its main purpose is to entertain, perhaps, as well as to inform. 


\section{CONCLUSION}

Talking about innovation is talking about something new or creative. Giving public information daily through on line medium before another papers doing in 1996 in Indonesia was the innovation that be done by Suara Merdeka. Recently, almost all papers in Indonesia have on line version. Besides, it served its community as a referent paper and a partner to solve community problems. Changing editorial policy accentuates on soft news also another innovation. All the innovation is working for the benefit financially to support its life in the future to compete with new technology.

\section{ACKNOWLEDGMENT}

I thank to the Dean of Social and Political Faculty of Diponegoro University that supports financially this research project in 2016. I also thank to all the informants to their time and willingness to be interviewed to complete this research data.

\section{REFERENCES}

[1] Albarran, Alan B. (2006). "Historical Trends and Patterns in Media Management Research". Alan B. Albarran (Editor), Handbook of Media Management and Economics. Mahwah: Lawrence Erlbaum Associates Publisher: 3-22
[2] Bagdikian, Ben H. (2004). The New Media Monopoly. Boston: Beacon Press

[3] Bell, Christopher. (2009). "Hard Versus Soft News". Christopher H. Sterling (General Editor), Encyclopedia of Journalism. Los Angeles: Sage Publication: 687-689

[4] Beam, Randal A. (2006). "Quantitative Methods in Media Management and Ecominics". Alan B. Albarran, Sylvia M. Chan-Olmsted and Michael O. Wirth, Handbook of Media Management and Economic.Mahwah, New Jersey: Lawrence Erlbaum Associates: 523552

[5] Haryanto, Ignatius. (2016). "Senja Kala Koran dan Jurnalisme Kita". Kompas (7 Januari): 7

[6] Kotler, Philip, Hermawan Kartajaya, and Iwan Setiawan. (2010). Marketing 3.0. Jakarta: Erlangga

[7] Machmud NS, Amir dan Triyanto Triwikromo. (2010). Arus Generasi Pengemas Informasi. Semarang: Masscom Graphy

[8] Newsom, Doug and James A. Wollert. (1985). Media Writing: News for the Mass Media. Belmont: Wadsworth Publishing Company

[9] Northouse, Peter G. (2013). Kepemimpinan: Teori dan Praktek (Edisi 6). Jakarta: Indeks

[10] O'Neill, Deirdre and Tony Harcup. (2009). "News Values and Selectivity". Karin Wahl-Jorgensen and Thomas Hanitzsch (Editors), The Handbook of Journalism Studies. New York: Routledge: 161-174

[11] Sumpter, Randall S. (2009)."News Values". Christopher H. Sterling (General Editor), Encyclopedia of Journalism. Los Angeles: Sage Publication: 1002-1005

[12] Sylvie, George, Jan LeBlanc Wicks, C. Ann Hollifield, Stephen Lacy, dan Ardyth Broaddrtick Sohn. (2008). Media Management: A Casebook Approach (4th ed.). New York: Routledge 